\title{
Afforestation with Norway spruce on a subalpine pasture alters carbon dynamics but only moderately affects soil carbon storage
}

\author{
David Hiltbrunner · Stephan Zimmermann • \\ Frank Hagedorn
}

Received: 24 September 2012/ Accepted: 11 February 2013/Published online: 1 March 2013

(C) Springer Science+Business Media Dordrecht 2013

\begin{abstract}
There is a strong trend toward reforestation of abandoned grasslands in alpine regions which may impact the carbon balance of alpine ecosystems. Here, we studied the effects of afforestation with Norway spruce (Picea abies L.) on an extensively grazed subalpine pasture in Switzerland on soil organic carbon (SOC) cycling and storage. Along a 120-year long chronosequence with spruce stands of 25, 30, 40, 45, and $>120$ years and adjacent pastures, we measured tree biomass, SOC stocks down to the bedrock, natural ${ }^{13} \mathrm{C}$ abundances, and litter quality. To unravel controls on SOC cycling, we have monitored microclimatic conditions and quantified SOC decomposability under standardized conditions as well as soil respiration in situ. Stocks of SOC were only moderately affected by the afforestation: in the mineral soil, SOC stocks transiently decreased after tree establishment, reaching a minimum 40-45 years after afforestation ( $-25 \%)$ and increased thereafter. Soils of the mature spruce forest stored the largest amount of SOC, $13 \%$ more than the pasture soils, mainly due to the accumulation of an organic layer ( $23 \mathrm{t} \mathrm{C} \mathrm{ha}^{-1}$ ). By comparison, $\mathrm{C}$ accumulated in the tree biomass exceeded the SOC
\end{abstract}

D. Hiltbrunner · S. Zimmermann · F. Hagedorn $(\bowtie)$ Swiss Federal Institute of Forest, Snow and Landscape Research (WSL), 8903 Birmensdorf, Switzerland e-mail: Hagedorn@WSL.CH

D. Hiltbrunner

Department of Geography, University of Zürich, 8057 Zurich, Switzerland pool by a factor of three in the old forest. In contrast to the small impact on $\mathrm{C}$ storage, afforestation strongly influenced the composition and quality of the soil organic matter (SOM). With increasing stand age, $\delta^{13} \mathrm{C}$ values of the SOM became consistently more positive, which can be interpreted as a gradual replacement of grass- by spruce-derived C. Fine roots of spruce were enriched in ${ }^{13} \mathrm{C}$, in lignin and had a higher $\mathrm{C} / \mathrm{N}$ ratio in comparison to grass roots. As a consequence, SOM quality as indicated by the lower fraction of readily decomposable (labile) SOM and higher C:N ratios declined after the land-use change. Furthermore, spruce plantation induced a less favorable microclimate for microbial activity with the average soil temperature during the growing season being $5{ }^{\circ} \mathrm{C}$ lower in the spruce stands than in the pasture. In situ soil respiration was approximately $50 \%$ lower after the land use conversion, which we primarily attribute to the colder conditions and the lower SOM quality, but also to drier soils $(-25 \%)$ and to a decreased fine root biomass $(-40 \%)$. In summary, afforestation on subalpine pastures only moderately affected SOC storage as compared to the large $\mathrm{C}$ sink in tree biomass. In contrast, SOC cycling rates strongly decreased as a result of a less favorable microclimate for decomposition of SOM, a lower C input by roots, and a lower litter quality.

Keywords Afforestation - Carbon storage · Carbon cycling - Organic matter quality . Soil respiration $\cdot$ Spruce $\cdot$ Alpine regions 


\section{Introduction}

Land use and land use change (LUC) are among the most important factors governing the carbon (C) fluxes between the terrestrial biosphere and the atmosphere and thus determining whether an ecosystem is a net source or sink for atmospheric $\mathrm{CO}_{2}$. While the tropical deforestation contributes to the rising $\mathrm{CO}_{2}$ level in the atmosphere, reforestation of abandoned agricultural areas on the Northern hemisphere, by contrast, increases the C sequestration (Houghton 2003). The net $\mathrm{C}$ uptake in these regions primarily results from agriculture extensification in conjunction with land use changes. Particularly in the European Alps, large areas of pasture have been abandoned in the last couple of decades for socio-economic reasons (MacDonald et al. 2000; Tappeiner et al. 2003). As a result, the forest cover strongly expanded due to woody plant encroachment (Hagedorn et al. 2010c; Tasser et al. 2007). In Switzerland, for example, the forested area in the Alps increased by $8 \%$ between 1995 and 2006, inducing an accumulation of tree biomass of 15 million $\mathrm{m}^{3}$ (Brändli 2010). The strong forest expansion is expected to continue particularly on marginal land of alpine regions due to the declining public support of agriculture and the decreasing attractiveness of farming (Bolliger et al. 2008). As a consequence, C storage in biomass is anticipated to increase significantly on a national scale.

As compared to $\mathrm{C}$ storage in biomass, the effects of reforestation on soil organic carbon (SOC) are much less studied and therefore ambiguous. Generally, afforestation is assumed to lead to an initial loss of SOC due to a higher $\mathrm{C}$ mineralization associated with soil disturbance at planting (Jandl et al. 2007). Thereafter, C stocks are expected to increase slowly until $\mathrm{C}$ input and mineralization equilibrates (Thuille and Schulze 2006). Whether the soil C stocks achieve the level previous to the land use change is uncertain and depends on different factors like climate, soil properties, tree species, or land use history (Guo and Gifford 2002; Paul et al. 2002; Post and Kwon 2000). A recent metadata analysis compiling LUC effects in the temperate zone revealed no clear trend in SOC stock changes in the mineral soils after afforestation of grasslands, which was partly attributed to the high variability among the studies (Poeplau et al. 2011). Moreover, since more than $80 \%$ of the studies only included surface soils, effects on subsoil were mostly neglected, which could lead to inaccurate estimates (Harrison et al. 2011). A further constraint in some of the studies is the distribution of chronosequences over rather large areas incorporating a high inherent heterogeneity. On a regional to countrywide scale, land use may have historically been selected according to the soil type, confounding the effects of vegetation type and land use history on soil C storage (Wiesmeier et al. 2012).

While most of the studies mainly focused on the total $\mathrm{C}$ stock changes, only a few assessments have addressed the underlying mechanism for the observed changes (Scott et al. 2006; Thuille and Schulze 2006). On the one hand, input pathways and litter composition considerably differ among plant species, with potential implications on soil organic matter (SOM) quality and C sequestration (De Deyn et al. 2008). In addition, vegetation type affects soil microbial communities and their metabolic activity (Berg and Smalla 2009; Macdonald et al. 2009), which govern the decay of organic matter and thus regulate $\mathrm{C}$ mineralization. On the other hand, afforestation can modify microclimatic conditions towards less favorable conditions for organic matter decomposition (Kellman et al. 2007; Smith and Johnson 2004). Whether afforestation leads to an increase or decrease of the SOC stocks strongly depends on the interaction of these processes and their modification by the LUC. Potential impacts of landuse changes might be higher at high than at low altitudes because alpine soils store relatively higher amounts of labile SOM than in lowlands due to a suppressed decomposition under unfavorable climatic conditions (Hagedorn et al., 2010c; Sjögersten-Turner et al. 2011). For instance, Budge et al. 2011 and Leifeld et al. 2009 observed percentages of 40-60\% in the uppermost $20 \mathrm{~cm}$ based on a combined density and particle size fractionation of SOM. On the other hand, the responses to LUC might be slower as plant productivity and soil $\mathrm{C}$ cycling rates are smaller (Sjögersten-Turner et al. 2011). Despite the strong increase in forest cover in alpine regions due to land abandonment, effects of afforestation have hardly been studied. In the Italian Alps, Thuille and Schulze (2006) observed increasing $\mathrm{C}$ stocks in the organic layer (approx. $+25 \mathrm{t} \mathrm{C} \mathrm{ha}^{-1}$ in 60 years) along chronosequences from grassland to forests, but initially declining SOC stocks in the mineral soil $(-15$ to $40 \mathrm{t} \mathrm{C} \mathrm{ha}^{-1}$ ) followed by a re-increase after some decades. In the Swiss Alps, by comparison, Risch et al. 
(2008) report a tendency of declining SOC stocks in topsoils along a several century-long succession from grasslands to stone pines. However, here it remains unclear, how much of the apparent SOC decline can be attributed to an earlier abandonment of marginal land with SOC-poorer soils on steeper slopes in a highly heterogeneous landscape.

In the present study, we wanted to investigate (1) how SOC-cycling and storage in relation to tree biomass changes along a 120-year old chronosequence of Norway spruce; and (2) to estimate which mechanisms drive the changes in SOC dynamics; in particular, how the afforestation has affected microclimatic conditions and how the altered input of plant litter has affected SOM) quality.

The whole chronosequence included 25, 30, 40, 45, and more than 120-year old forest stands, established on an extensively grazed subalpine pasture within a rather small area on an even slope, which provided homogeneous soil conditions within the whole study site. Here, we quantified SOC-stocks and SOM quality in relation to land use and stand age. Furthermore, we measured soil respiration in situ and $\mathrm{C}$ mineralization under standardized conditions to disentangle controls of $\mathrm{C}$ cycling and storage as affected by the vegetation change. We hypothesized that (i) soils would lose C, primarily during the first years after the planting as a result of soil disturbance and a declining $\mathrm{C}$ input by roots in the upper mineral soil; that (ii) the C-stocks would begin to increase in the older stands mainly due to an accumulation of a forest floor; that (iii) the afforestation would lead to a 'colder' microclimate with less favorable conditions for $\mathrm{C}$ mineralization; and that (iv) SOM quality would decline.

\section{Materials and methods}

Study site

The study was conducted in a sub-alpine region in the Canton of Fribourg, Switzerland $\left(7^{\circ} 15^{\prime} 54 \mathrm{E} ; 46^{\circ} 37^{\prime} 17 \mathrm{~N}\right)$, on a south-facing slope reaching from 1,450 to $1,800 \mathrm{~m}$ a.s.l. Mean summer and winter air temperatures are 11.4 and $0.6{ }^{\circ} \mathrm{C}$, respectively; mean annual precipitation averages $1,250 \mathrm{~mm}$ with a maximum in summer.

The entire slope has been under pasture for at least 150 years, but most likely it was used for cattle grazing for several centuries. After severe avalanches in 1956, the eastern part of the slope was gradually afforested with Norway spruce (Picea abies L.), while the western part remained as a pasture (Fig. 1). Since the trees were planted within a time span of two decades, the afforestations differ in age $(25,30,40$, and 45 years old). In addition, a mature spruce forest (older than 120 years), representing a permanent forest ecosystem, was used as a control (Fig. 1). We selected the stands based on observed stand properties in the field and on information from the forest management plan (tree ages, method of planting, stand density, implemented forest management options) and determined the precise stand age by dendrochronological analysis.

Soils across the whole slope were Eutric Cambisols on calcareous bedrock with a mean thickness of $80 \mathrm{~cm}$ and carbonate-free to an average depth of $60 \mathrm{~cm}$. While in the pasture an organic layer was lacking, soils of the afforstations had an Oi- and Oe horizon and the mature forest additionally had an Oa horizon. The mineral soil was characterized by an approximately $20 \mathrm{~cm}$ thick A-horizon, followed by a B-horizon, partly featuring manganese concretions and iron mottles below $40 \mathrm{~cm}$. The C-horizon started at $\sim 60 \mathrm{~cm}$ depth and contained calcareous bedrock material. All soils had clay contents around $50 \%$ except one of the 40-year old stands with a clay content of only $20 \%$ and a sand fraction of $70 \%$ (Table 1). Soil $\mathrm{pH}$ ranged between 4 and 7 with significantly higher values in the deeper soils but it did not significantly differ among the vegetation types. Soil $\mathrm{pH}$ under pasture was not affected by altitude but slightly increased along the horizontal gradient towards the Eastern part of the slope $(P=0.02)$. Nevertheless, visual characterization of the soil profiles as well as analyses of the samples showed rather homogeneous soil properties within the whole study site.

Soil sampling

Soils were sampled along four transects at different altitudes, ranging from the pasture into the forest stands ( $n=4$ blocks). Each section of the transect differing in land use or stand age was regarded as a plot $(n=11)$ and in each plot, 5 or 10 soil pits were dug with a distance of $10 \mathrm{~m}$ between each other. A fifth transect at $1,680 \mathrm{~m}$ a.s.l. with 20 soil pits only within the pasture was used to test the homogeneity of soils along the slope (Fig. 1). In each soil pit, soil morphology and stone content were estimated visually. Soil samples for chemical analyses were taken at 


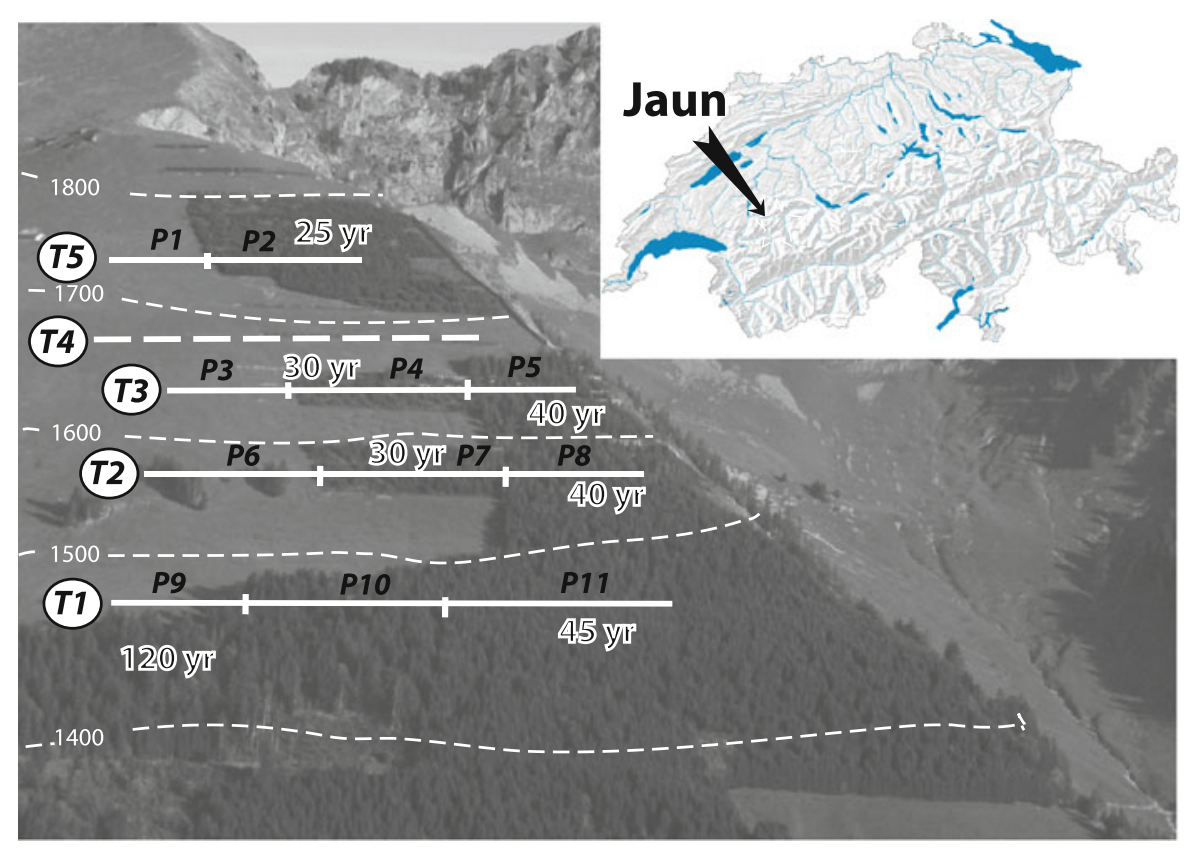

Fig. 1 Study site with the different transects $(T 1-T 5)$ and the 11 plots $(P 1-P 11)$ where soils have been sampled. Pasture transect $T 4$ was used to test horizontal homogeneity of the slope

Table 1 Bulk density, clay content and soil pH $( \pm$ SE) in the different plots in 0-10 and 20-30 cm depth

\begin{tabular}{|c|c|c|c|c|c|c|c|}
\hline Land use stand age & Altitude & $\begin{array}{l}\mathrm{BD}\left(\mathrm{kg} \mathrm{dm}^{-3}\right) \\
0-10 \mathrm{~cm}\end{array}$ & Clay (\%) & $\mathrm{pH}$ & $\begin{array}{l}\mathrm{BD}\left(\mathrm{kg} \mathrm{dm}^{-3}\right) \\
20-30 \mathrm{~cm}\end{array}$ & Clay (\%) & $\mathrm{pH}$ \\
\hline Pasture & 1,450 & $0.87(0.05)$ & 53 & $5.5(0.2)$ & $1.05(0.02)$ & NA & $5.3(0.2)$ \\
\hline Pasture & 1,520 & $0.83(0.05)$ & 54 & $4.8(0.1)$ & $1.08(0.03)$ & 52 & $4.7(0.1)$ \\
\hline Pasture & 1,610 & $0.83(0.03)$ & 50 & $4.7(0.1)$ & $1.01(0.02)$ & 49 & $4.8(0.2)$ \\
\hline Pasture & 1,700 & $0.81(0.03)$ & 56 & $5.2(0.1)$ & $1.11(0.02)$ & 52 & $5.8(0.3)$ \\
\hline Forest 25 years & 1,700 & $0.75(0.02)$ & 61 & $5.1(0.2)$ & $1.08(0.03)$ & 63 & $5.7(0.2)$ \\
\hline Forest 30 years & 1,520 & $0.81(0.03)$ & 51 & $4.8(0.2)$ & $1.05(0.04)$ & NA & $5.0(0.2)$ \\
\hline Forest 30 years & 1,610 & $0.84(0.05)$ & 58 & $5.7(0.3)$ & $1.14(0.03)$ & NA & $6.0(0.3)$ \\
\hline Forest 40 years & 1,520 & $0.83(0.05)$ & 41 & $4.3(0.1)$ & $1.07(0.04)$ & 41 & $4.8(0.1)$ \\
\hline Forest 40 years & 1,510 & $0.87(0.02)$ & 20 & $4.6(0.2)$ & $1.17(0.04)$ & 20 & $5.4(0.3)$ \\
\hline Forest 45 years & 1,450 & $0.78(0.02)$ & 50 & $4.1(0.1)$ & $1.08(0.02)$ & NA & $4.9(0.3)$ \\
\hline Forest 120 years & 1,450 & $0.72(0.03)$ & 49 & $4.5(0.2)$ & $1.01(0.06)$ & NA & $5.0(0.2)$ \\
\hline
\end{tabular}

$N A$ not measured, $S E$ standard error

six different depths $(0-5,5-10,10-20,20-40,40-60$, and $60-80 \mathrm{~cm})$. Bulk density was determined at two depths (0-10 and 20-30 cm) in every second soil pit ( $n=60)$ using steel cylinders with a volume of $1,000 \mathrm{~cm}^{3}$. In an additional seven soil pits across the whole site, bulk density was measured down to the bedrock in triplicates. The organic layer was sampled on an areal basis with a steel frame $(0.25 \times 0.25 \mathrm{~m})$ for each organic horizon individually ( $n=8-20$ per plot).

Soil physical analyses, stone content, and root biomass

Bulk soil density was calculated with the mass of the oven dried $\left(105^{\circ} \mathrm{C}\right)$ soil weight divided by the volume 
of the cylinder. From a subset of the soil cores stone content $(0-10,20-30 \mathrm{~cm} ; n=75)$ and root biomass $(0-10 \mathrm{~cm} ; n=28)$ were determined by consecutively sieving the soils to $2 \mathrm{~mm}$ (stones), 1 and $0.5 \mathrm{~mm}$ (roots) under a gentle stream of water. The retained fine rock material and plant roots were thoroughly cleaned from soil particles, dried at $105{ }^{\circ} \mathrm{C}$ and weighted to calculate fine rock volume and root biomass of the soils. Soil texture was determined with the pipette method according to Gee and Bauder (1986).

Tree biomass estimation

Diameter of all trees was measured in two areas of $25-100 \mathrm{~m}^{2}$ in the younger stands (up to 30 years) and in a single larger area of $250-600 \mathrm{~m}^{2}$ in the older afforestations to account for the bigger size and lower density of trees. In addition, the heights of 5-10 single trees per area were measured. Biomass of the single trees was calculated using allometric functions depending on stem diameter at breast height and tree height (Kaufmann 2001) and total biomass was related to the basal area per ground area.

Chemical analyses of plant and soil samples

Prior to chemical analysis, soil samples were ovendried $\left(60{ }^{\circ} \mathrm{C}\right)$, sieved $(2 \mathrm{~mm})$ and ground. Soil $\mathrm{pH}$ was measured potentiometrically in $0.01 \mathrm{M} \mathrm{CaCl}_{2}$ with a solid/extractant ratio of 1:2.

Since the parent material of the site is calcareous, mineral soil samples with $\mathrm{pH}>6$ were fumigated with $\mathrm{HCl}$ in order to remove inorganic $\mathrm{C}$ (Walthert et al. 2010). $\mathrm{C}$ and $\mathrm{N}$ concentrations and the carbon isotopic ratio $\left(\delta^{13} \mathrm{C}\right)$ of plant and organic layer material and a subset of the mineral soil samples $(n=250)$ were measured with an automated elemental analyser-continuous flow isotope ratio mass spectrometer (Euro-EA, Hekatech GmbH, Germany, interfaced with a Delta-V Advanced IRMS, Thermo GmbH, Germany). C and N concentrations of the remaining mineral soil samples $(n=350)$ were measured with an elemental analyser coupled with a thermal conductivity detector (NC-2500, CE-Instruments, Italy). Results of the $\mathrm{C}$ isotope analysis were expressed in $\delta$ units (\%o) relative to Vienna Pee Dee belemnite (V-PDB) standard.

In plant samples, Klason lignin was gravimetrically determined as the residue of $500 \mathrm{mg}$ of finely ground plant material after being consecutively extracted with $12.5 \mathrm{~mL}$ of hot water $\left(80{ }^{\circ} \mathrm{C}\right), 12.5 \mathrm{~mL}$ of ethanol, hydrolysed for $1 \mathrm{~h}$ with $1.5 \mathrm{~mL}$ of $72 \%$ sulphuric acid at $30{ }^{\circ} \mathrm{C}$ and after the addition of $42 \mathrm{~mL}$ of water, autoclaved for $1 \mathrm{~h}$ at $120^{\circ} \mathrm{C}$. Total lignin concentration was the sum of Klason lignin and the soluble lignin, which was estimated from the UV absorbance of the hydrolysate at $205 \mathrm{~nm}$ (Dence 1992).

Microclimate and soil respiration

Soil temperature and volumetric water content (VWC) were continuously recorded over one and a half year under pasture and in the 40 year old forest at 5, 25, and $50 \mathrm{~cm}$ depth using Decagon sensors (5TM) and data loggers (Em50R, Decagon Devices Inc., Pullman, WA, USA). Additional manual measurements were conducted concomitantly with the soil respiration measurements using a thermometer and time domain reflectometry (TDR) probes (TRIME-FM, IMKO, Germany) to test the effect of microclimate on soil respiration (covariates in the statistical model).

Soil respiration was measured using a static chamber technique (Hiltbrunner et al. 2012). In each of the eleven plots, four PVC-chambers $(32 \mathrm{~cm}$ diam. $\times 30 \mathrm{~cm}$; $n=44)$ were inserted $20 \mathrm{~cm}$ into the soil, with the remaining headspace volume of each chamber was determined individually. The chambers were installed 2 months before the first measurement in order to ensure the recovery of soils from physical disturbance and grass was cut at several dates. Soil respiration rates were determined at six dates (July 17, August 10, 13 and 20, September 3, and October 1, 2010) by closing the chambers with an air-tight lid and sampling the headspace with a syringe through a septum after 5, 20, and $35 \mathrm{~min}$. Gas samples were subsequently analyzed for $\mathrm{CO}_{2}$ concentrations with a gas chromatograph (Agilent 7890, fitted to a flame ionisation detector (FID), Agilent Technologies Inc. CA, USA) and respiration rates were calculated by linear regression of the $\mathrm{CO}_{2}$ concentrations against sampling time.

Substrate induced respiration (SIR) and C-mineralization

For the incubation experiments, sampled soils from the Oi-horizon $(n=8)$, the Oe-horizon $(n=4)$, and four replicates of the uppermost $5 \mathrm{~cm}$ of mineral soil from each plot $(n=44)$ were immediately transported 
to the laboratory, where they were sieved $(4 \mathrm{~mm})$ and the roots were removed. Samples were stored at $4{ }^{\circ} \mathrm{C}$ for 1 week prior to the incubation.

SIR, as an indicator for microbial biomass, was measured in a $\mathrm{CO}_{2}$ measuring system with a continuous $\mathrm{CO}_{2}$-free air flow as described by Cheng and Virginia (1993). Briefly, $40 \mathrm{~g}$ fresh mineral soil and $10 \mathrm{~g}$ organic layer material was placed into airtight jars and amended with $8 \mathrm{~mL}$ glucose solution (50 $\mathrm{g} \mathrm{L}^{-1}$ for mineral soils and $12.5 \mathrm{~g} \mathrm{~L}^{-1}$ for organic layer material, resulting in $10 \mathrm{mg}$ glucose $\mathrm{g}^{-1}$ sample). $\mathrm{CO}_{2}$ release of the samples was determined after $1 \mathrm{~h}$ by measuring $\mathrm{CO}_{2}$ concentration with an infrared gas analyzer (LI 840, LI-COR, NE, USA) at an air flow rate of $160 \mathrm{~mL} \mathrm{~min}^{-1}$.

To estimate $\mathrm{C}$ mineralization of the soils under standardized conditions, mineral soil samples and organic layer material was incubated during 140 days at $20{ }^{\circ} \mathrm{C}$ in the dark. $20 \mathrm{~g}$ mineral soil and $3 \mathrm{~g}$ organic layer material were placed into $120 \mathrm{~mL}$ jars and after measuring the respiration rates the first time under field moist conditions, water contents were adjusted to $50 \%$ of the water holding capacity. $\mathrm{CO}_{2}$ production of the samples was measured periodically in a closed system; after tightening the jars with a rubber stopper, air from the headspace circled through an infrared gas analyzer (LI 840, LI-COR, NE, USA) and respiration rates were calculated by linear regression of the $\mathrm{CO}_{2}$ concentrations against time.

\section{Calculations and statistical analysis}

SOC stocks were calculated per plot by multiplying SOC concentrations with soil bulk densities and thicknesses of each depth class by using the rules of error propagation. Bulk densities between 10 and $20 \mathrm{~cm}$ were interpolated from the measured values in 0-10 and 20-30 cm depth. In addition, bulk densities were corrected for stone contents according to measurements of the fine rock fraction and visual estimation of the coarse rocks in the soil pits (see "Results" section) assuming a rock density of 2.65 .

We analyzed our data by fitting mixed-effects models by maximum likelihood (lme function from the nlme package, R 2.10.1, R Development Core Team (2010)). The model included the sequential fixed effects land use (pasture vs. forest), forest stand age as a linear contrast and soil depth where appropriate. Reflecting the structure of the experiment, the nested random effects were block, plot, and where appropriate, soil depth. The homogeneity of the slope was tested by applying a linear model (aov function) with the data from the pasture soils only. The variables included were either altitude ( $\mathrm{m}$ a.s.l.) or position along the horizontal gradient and soil depth. Effects with $P<0.05$ were considered statistically significant, effects with $0.05<P<0.1$ as marginally significant.

\section{Results}

Bulk density and rock content

Bulk density ranged between 0.7 and $0.9 \mathrm{~kg} \mathrm{dm}^{-3}$ in the surface soil $(0-10 \mathrm{~cm})$ and $1.0-1.2 \mathrm{~kg} \mathrm{dm}^{-3}$ between 20 and $30 \mathrm{~cm}$ depth with the afforestations being not significantly different from the pasture ( $P=0.8$; Table 1$)$. However, the lowest bulk density was recorded at both depths in the old forest resulting in a stand age effect close to significance $(P=0.06)$. The stone content up to a depth of $50 \mathrm{~cm}$ was surprisingly low for alpine soils. Smaller rock fragments $(>2 \mathrm{~mm})$ determined by the sieving of soil material sampled with cores, accounted for about $1 \%$ of the soil volume in the surface layer and up to $8 \%$ in the $20-30 \mathrm{~cm}$ layer. In addition, we visually estimated the fraction of coarse stones not included in the sampled soil cores. The resulting total rock content, which was also used for $\mathrm{C}$ stock calculation, was on average $5,10,15,20$, and $40 \%$ for the $0-10,10-20$, 20-40, 40-60, and 60-80 cm layers, respectively.

SOC concentrations and stocks

Soil carbon concentrations significantly decreased with soil depth in all the plots $(P<0.001$; Fig. 2$)$, indicating that the soils had not been disturbed or affected by erosion or landslides in the recent past. We tested the spatial homogeneity of SOC concentration of the study site by an altitudinal and horizontal gradient within the pasture. Neither altitude $(P=0.4)$ nor horizontal position $(P=0.12)$ significantly affected SOC concentrations. In fact, the soil $\mathrm{C}$ concentrations along the pasture transect at $1,680 \mathrm{~m}$ a.s.l. slightly increased towards the Eastern part of the slope, which is in contrast to the lower $\mathrm{C}$ stocks of the forest stands on the Eastern part further down the slope at 1,610 and 1,560 m a.s.l. (Fig. 1). By comparison to the small variability in the pasture, SOC 
concentration in the surface mineral soils $(0-10 \mathrm{~cm})$ showed a distinct pattern along the afforestation chronosequence, with the highest values under pasture and in the old forest ( $\sim 60 \mathrm{mg} \mathrm{C} \mathrm{g}^{-1}$ ) and the lowest values in the 40 and 45 years old stands $\left(\sim 43 \mathrm{mg} \mathrm{C} \mathrm{g}^{-1}\right)$ (Fig. 2). The same pattern was also apparent in the subsoils, with the lowest SOC concentrations in the 40 and 45 years old stands. Statistically, the transient decline of SOC was evidenced when the old forest was excluded from the analysis by linear mixed model $\left(P_{\text {stand }}\right.$ age $<0.01)$.

Total SOC stocks ranged between 112 and $154 \mathrm{t} \mathrm{C} \mathrm{ha}^{-1}$, of which $83-100 \%$ was stored in the mineral soil and the remainder in the organic layer (Fig. 1). Reflecting the SOC concentrations, SOC stocks of the mineral soils were only slightly altered in the first years following the tree plantation, but strongly declined after 30 years, with the lowest stocks in the 40 and 45 years old stands (Fig. 3). In the old forest, mineral soil SOC stocks were in the same range as the ones under pasture. Carbon stocks in the organic layer increased from $0 \mathrm{t} \mathrm{Cha}^{-1}$ in the pasture to approximately $25 \mathrm{t} \mathrm{C} \mathrm{ha}^{-1}$ in the 45 -year old forest and did hardly change to the old forest. The increasing $\mathrm{C}$ storage in the organic layer with stand age but decreasing $\mathrm{C}$ stocks in the mineral soil resulted in only slightly decreasing total soil $\mathrm{C}$ stocks from the pasture to the 45 year old forest stands. The old forest had the highest total soil C stocks, with approximately $20 \mathrm{t} \mathrm{ha}^{-1}$ more $\mathrm{C}$ stored than in the soil of the pasture. This increase corresponded to $60 \%$ higher $\mathrm{C}$ stocks when only the organic layer and the uppermost $10 \mathrm{~cm}$ were included and to $13 \%$ higher stocks when the total soil profiles were considered.

Tree biomass strongly contributed to the increasing $\mathrm{C}$ storage with afforestation (Fig. 3). In the 25 years old afforestation, an additional $86 \mathrm{t} \mathrm{C} \mathrm{ha}^{-1}$ was fixed in the plant biomass (above and belowground) and this pool size increased up to $420 \mathrm{tC} \mathrm{ha}^{-1}$ in the old forest. Here, approximately three times the amount of SOC was stored in the tree biomass.

Composition and quality of litter, fine roots and SOM

Chemical composition of the organic matter, as expressed by $\mathrm{C}: \mathrm{N}$ ratios and ${ }^{13} \mathrm{C}$ natural abundances, strongly changed during decomposition (i.e., with soil depth in all soils; Figs 2, 4). Fine root biomass ( $<2 \mathrm{~mm})$ in the uppermost $10 \mathrm{~cm}$ amounted to $0.6 \mathrm{~kg} \mathrm{~m}^{-2}$ under forest and to $1 \mathrm{~kg} \mathrm{~m}^{-2}$ under pasture. Grass roots were enriched in $\mathrm{N}(\mathrm{C}: \mathrm{N}$ ratio $=49)$ and had a lower lignin content (230 $\mathrm{mg} \mathrm{g}^{-1}$ ) compared to the spruce fine roots $\left(\mathrm{C}: \mathrm{N}\right.$ ratio $=69$, lignin content $=310 \mathrm{mg} \mathrm{g}^{-1}$, respectively) suggesting a higher decomposability of the grass roots. In addition, grass tissue contained a higher proportion of $\mathrm{N}$ and less lignin than spruce needles (Table 2). Reflecting the altered above and belowground $\mathrm{C}$ input following the afforestation, soil $\mathrm{C}: \mathrm{N}$ ratios were significantly narrower under pasture than under forest $(P=0.02)$ and increased with stand age $(P=0.04)$. However, the effect of vegetation on soil $\mathrm{C}: \mathrm{N}$ ratios was only apparent up to a depth of $40 \mathrm{~cm}$ but not in the deeper soils. The $\delta^{13} \mathrm{C}$ values of soils under forest were significantly higher than the ones under pasture $(P<0.01$; Fig. 4). Similar to the soil C:N ratios, the effect of vegetation on soil $\delta^{13} \mathrm{C}$ signature was most pronounced in the surface soil while it decreased with increasing soil depth and vanished below $20 \mathrm{~cm}$. In the uppermost mineral soil $(0-5 \mathrm{~cm})$, the difference between the two land use types amounted to about $1.5 \%$. After tree plantation, $\delta^{13} \mathrm{C}$ values at $0-5 \mathrm{~cm}$ became gradually more positive with increasing stand age (Fig. 4), shifting from $-27 \%$ under pasture to $25.5 \%$ under the old forest.

Soil respiration, microbial activity, and microclimate

Soil respiration changed strongly along the chronosequence. Average soil respiration rates (July-October) ranged between $2.3 \mu \mathrm{mol} \mathrm{CO}_{2} \mathrm{~m}^{-2} \mathrm{~s}^{-1}$ in the youngest stand and $6.4 \mu \mathrm{mol} \mathrm{CO} \mathrm{CO}^{-2} \mathrm{~s}^{-1}$ in the pasture. As expected, soil respiration was strongly driven by soil temperature $(P<0.001)$, but not by soil moisture $(P=0.4)$. Microclimatic measurements showed about $5{ }^{\circ} \mathrm{C}$ lower soil temperatures at $5 \mathrm{~cm}$ depth under forest than under pasture during the growing season (April-September) (Fig. 5). In winter, the difference in temperature between the two vegetation types was smaller but the forest soils were frozen for a longer time period than the pasture soils. Moreover, forest soils had considerably lower volumetric water contents than pasture soils (Fig. 5). Mean soil moisture contents at $5 \mathrm{~cm}$ depth measured using TDRprobes concomitantly to soil respiration were $0.29 \mathrm{~m}^{3} / \mathrm{m}^{3}$ under forest $(n=1,304)$ and $0.39 \mathrm{~m}^{3} / \mathrm{m}^{3}$ under pasture $(n=668)$, respectively. However, even after 
Fig. 2 Depth profiles of SOC concentrations and $\mathrm{C}: \mathrm{N}$-ratios $( \pm \mathrm{SE})$ along the four transects at different altitudes under pasture and different aged spruce stands

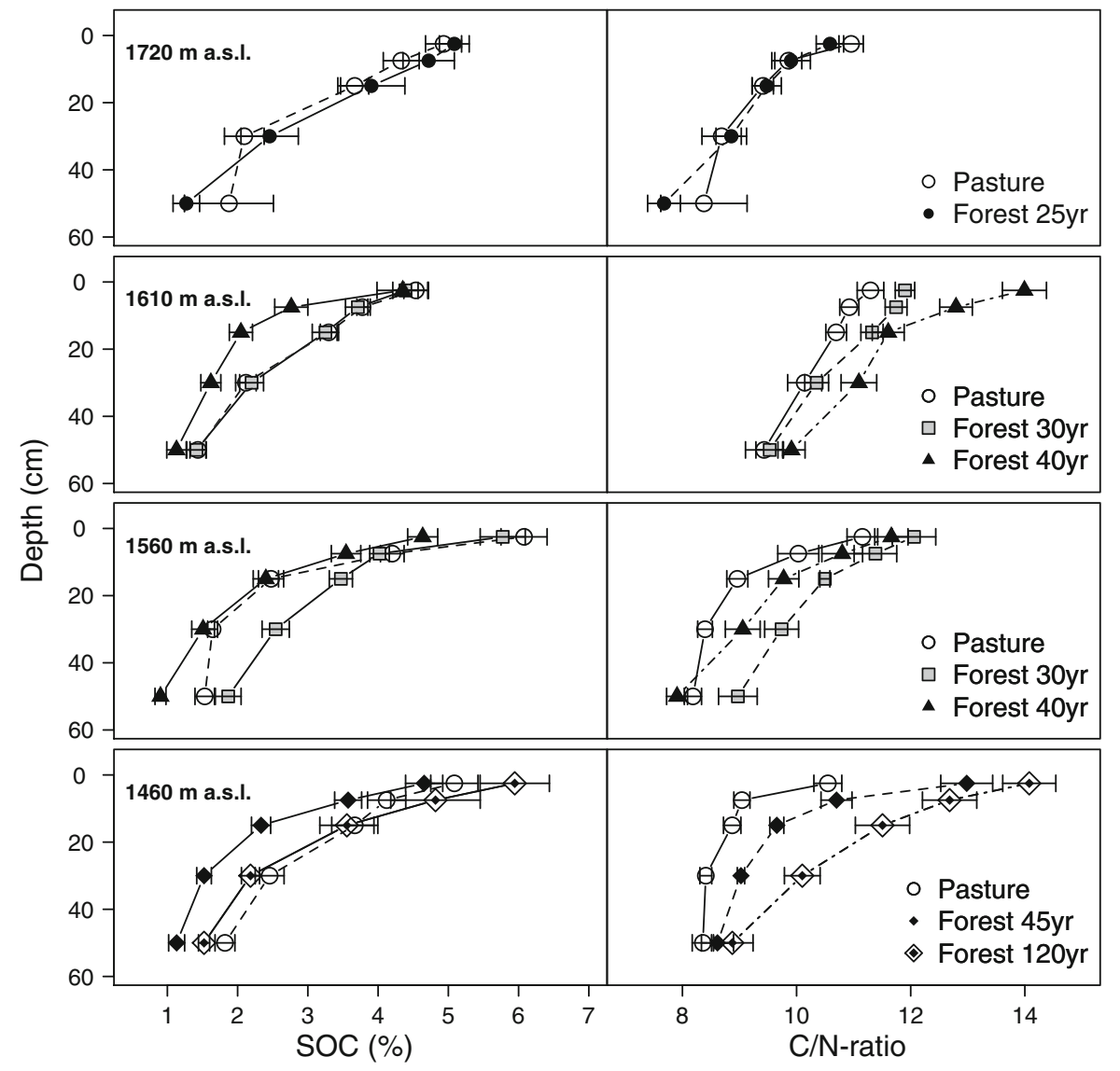

Fig. 3 C-stocks in the different compartments $( \pm \mathrm{SE})$ in the pasture and different aged spruce stands with mineral soils being $80 \mathrm{~cm}$ thick. Small figure displays soil $\mathrm{C}$ stocks in the uppermost $10 \mathrm{~cm}$ of mineral soil and organic layers

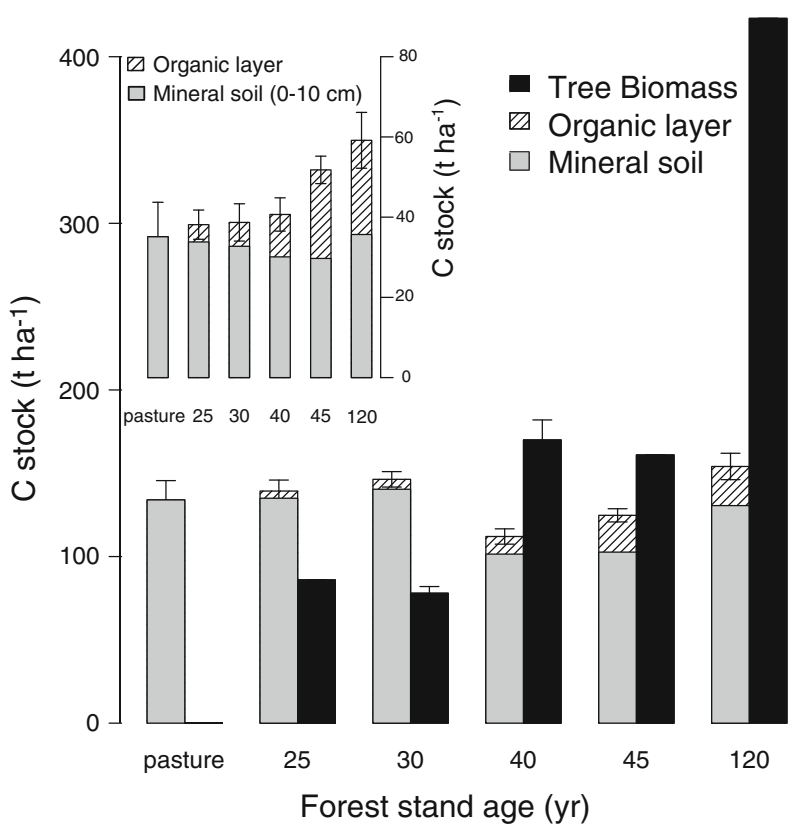


Fig. 4 Natural abundance of the ${ }^{13} \mathrm{C}$ isotope $( \pm \mathrm{SE})$ of the plant material and the SOM at different depths under pasture and different aged spruce stands

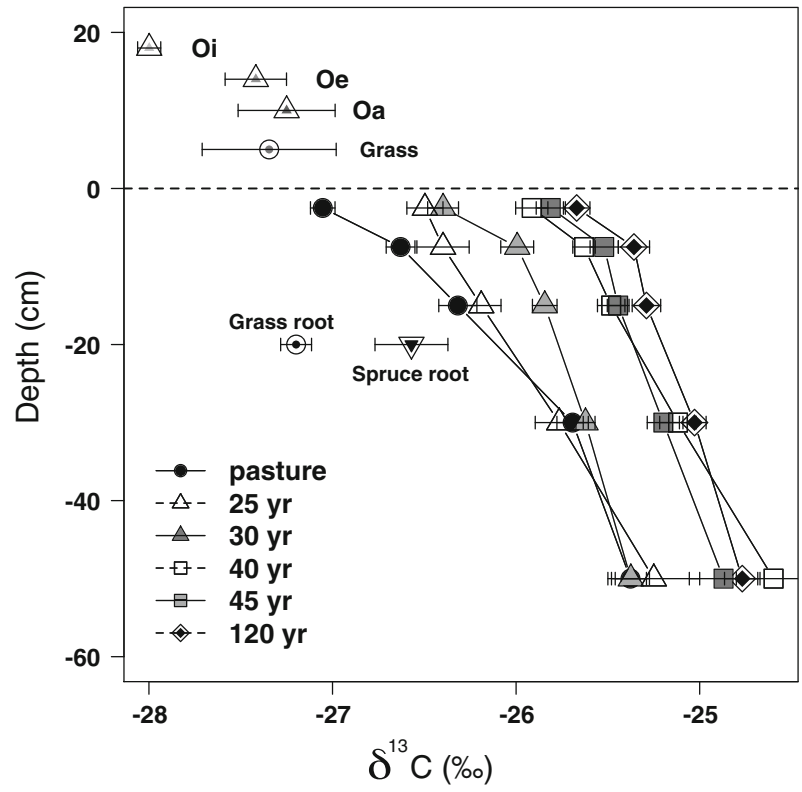

the microbial biomass $P=0.09$ ). Not unexpectedly, $\mathrm{C}$ mineralization was positively affected by the soil $\mathrm{C}$ content of the mineral soil samples $(P<0.001)$. As a result, when $\mathrm{C}$ mineralization was related to $\mathrm{g}$ soil $\mathrm{C}$, pasture soils released significantly more $\mathrm{CO}_{2}$ $(P<0.01$ for both), indicating that SOC contained a larger proportion of labile SOM in the pasture than in the forest. $\mathrm{C}$ mineralization in the organic horizons was 10-20 times higher than in the mineral soils and the mineralization rates of the organic layer material were positively correlated with the $\mathrm{C}: \mathrm{N}$ ratios $(P=0.003)$.

\section{Discussion}

Our chronosequence study shows that afforestation with spruce on an alpine pasture decreased soil respiration rates, altered soil organic matter quality and induced less favorable microclimatic conditions. However, the afforestation had only a moderate impact on total soil $\mathrm{C}$ stocks, with an accumulation of forest floor and a small transient decline of $\mathrm{C}$ stocks in the mineral soil.

The detection of changes in soil $\mathrm{C}$ stocks through afforestation by the "space for time" approach applied in this and other studies relies on homogeneous soil conditions. This is particularly important given that our study site spanned an altitudinal gradient of $250 \mathrm{~m}$, along which temperatures and length of vegetation fitting soil temperature and soil moisture as covariates into the model, soil respiration was still significantly higher in the pasture plots $(P=0.02)$.

Under standardized conditions in the laboratory, $\mathrm{C}$ mineralization per gram dry and root-free soil did not significantly differ between pasture and forest mineral soils (Figs. 6, 7), either for the cumulative amount of respired $\mathrm{C}$ at the end of the incubation $(P=0.11)$ or the amount of $\mathrm{C}$ after glucose addition (as a measure for 
Fig. 5 Soil temperature and soil moisture at 5 and $25 \mathrm{~cm}$ depth under pasture and in a 40-years old spruce stand

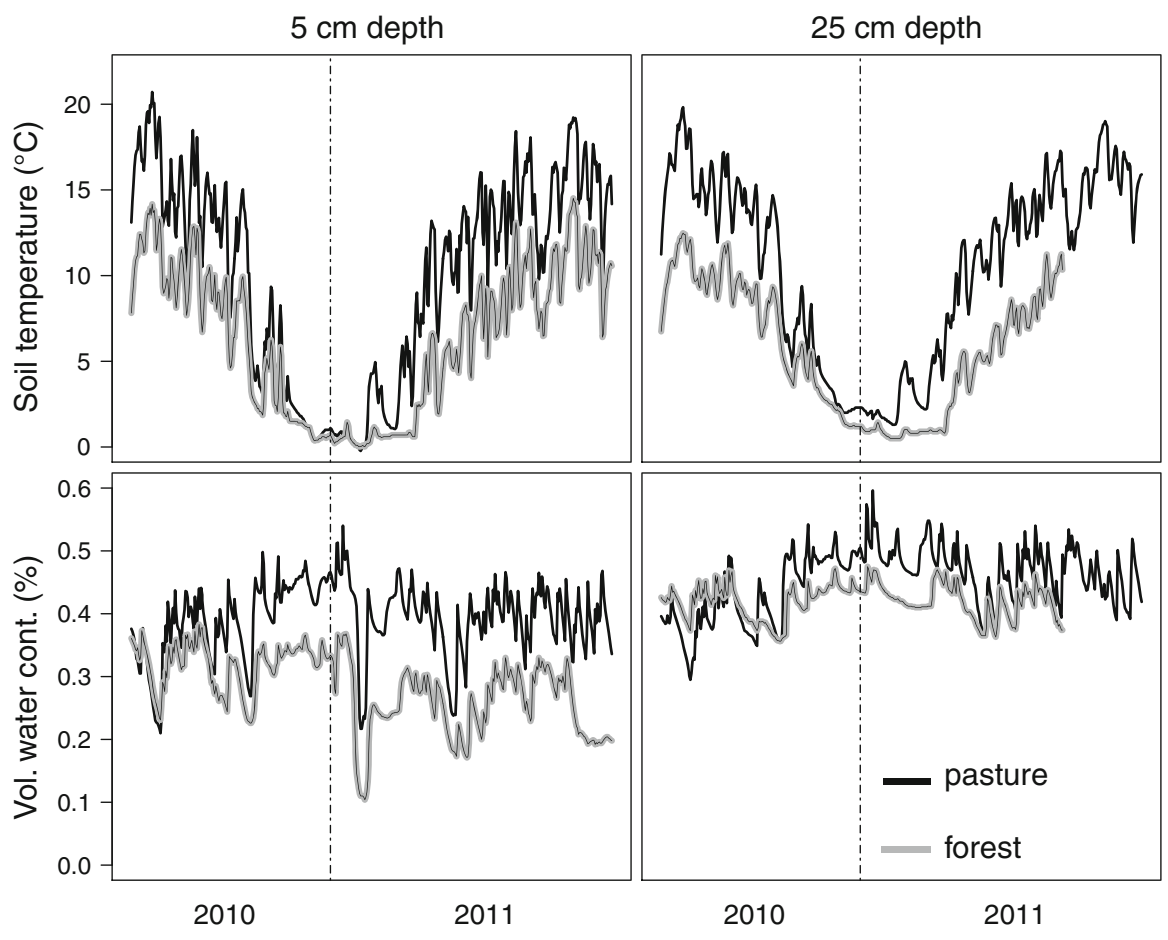

period changes, which, in turn, might affect organic matter input and turnover. For example, in a Swiss alpine pasture, root biomass increased by $25 \%$ and turnover times almost doubled between 1,665 and 2,520 $\mathrm{m}$ a.s.1. (Hitz et al. 2001). Accordingly, Leifeld et al. (2005) estimated for Swiss alpine grasslands that SOC-concentrations at $0-20 \mathrm{~cm}$ depth increase with altitude at a rate of about $2 \mathrm{mg} \mathrm{C} \mathrm{g}^{-1}$ per $100 \mathrm{~m}$. However, at our study site, we did not find statistical differences in SOC concentrations within the pasture soils, either along the altitudinal gradient or along an East-West transect encompassing 20 soil pits under pasture (Fig. 1). Moreover, soil properties such as soil texture, stone content, soil density, thickness of the soil horizons, and soil color were also very homogeneous across the whole slope (Table 1).

Moderate effects on soil $\mathrm{C}$ pools

Soil organic $\mathrm{C}$ stocks of the mineral soils ranged between 101 and $140 \mathrm{t} \mathrm{C}$ ha $^{-1}$ which is higher than the ones reported by Thuille and Schulze (2006) in a series of different aged spruce afforestations in the Alps and Thuringia (40-100 t C ha ${ }^{-1}$ for the whole soil profile) but close to the mean value for Swiss alpine forest soils ( $\sim 130 \mathrm{t} \mathrm{C} \mathrm{ha}^{-1}$ ) (Hagedorn et al. 2010b). The gradual accumulation of forest floor at a rate of $0.19 \mathrm{t} \mathrm{C} \mathrm{ha}^{-1}$ years ${ }^{-1}$ resulted in an additional $23 \mathrm{t} \mathrm{C} \mathrm{ha}^{-1}$ stored in the old forest. Taking this $\mathrm{C}$ pool into calculation, the soil $\mathrm{C}$ pool in the old forest exceeded the one of the pasture soils by $20 \mathrm{t} \mathrm{ha}^{-1}$ (Fig. 3), which is close to the average difference of $22 \mathrm{t} \mathrm{ha}^{-1}$ between the two land use types in Switzerland (Bolliger et al. 2008). By comparison, SOC stocks of the mineral soil transiently decreased in the 40 and 45 years old stands and increased again in the old forest (Fig. 3). This pattern is in line with the findings of other chronosequence studies along afforestation (Poeplau et al. 2011; Thuille and Schulze, 2006), although the main C loss in our study apparently occurred with a time lag of a few decades after the tree plantation. In general, the magnitude of soil $\mathrm{C}$ loss with afforestation principally depends on the degree of disturbance with site preparation (Jandl et al. 2007) and the persistence of the grass cover providing a sustained input of fine root C into mineral soils (Thuille and Schulze 2006). In this study, soil disturbance at planting and hence $\mathrm{C}$ losses through mineralization were minimal as the spruce saplings were planted manually on the relatively steep subalpine slope. This might explain that the main $\mathrm{C}$ loss in the surface soil did not occur directly after the tree plantation but was more closely related to the 
cessation of the dense grass cover with tree canopy closure 20-30 years after afforestation. We also have hypothesized that the C-loss would primarily occur in the topsoil due to declining fine root densities and the development of deeper rooting systems following afforestation (Jackson et al. 1996). However, our data suggest the opposite, $\mathrm{C}$ was primarily lost from the subsoil. Afforestation effects on SOC stored in the deeper soil layer are ambiguous to date as the majority of the LUC studies only comprised topsoils. While some studies found that afforestation increases C storage in the subsoil (Hooker and Compton 2003; Ouimet et al. 2007; Wei et al. 2012), others reported declining C stocks (Thuille and Schulze 2006; Ouimet et al. 2007). After afforesting cotton fields with loblolly pine, Richter et al. (1999) observed increasing C stocks in the surface soil accompanied by a loss of $\mathrm{C}$ in the deeper soil layers. Their analysis of ${ }^{13} \mathrm{C}$ and ${ }^{14} \mathrm{C}$ isotopes indicated that these $\mathrm{C}$ losses from the deeper soil occurred despite a substantial input of new root $\mathrm{C}$ and DOC. These new $\mathrm{C}$ inputs, however, were not stabilized but probably instead might have stimulated the decomposition of existing SOC (Mobley 2011). Since subsoils are lacking energy-rich substrate needed for soil microbes to maintain their metabolism, they presumably are more prone to priming than surface soils with higher C availability (Fontaine et al. 2007).

Our data clearly show the importance of the chosen sampling depth for the interpretation of the results (Harrison et al. 2011). If we had included only the organic layer and the uppermost mineral soil $(0-10 \mathrm{~cm})$, the afforestation would have increased the soil C stocks by $60 \%$. However, if the whole soil profile is taken into account, the afforestation effect is much smaller $(\sim 13 \%)$ and $\mathrm{C}$ stocks depend more strongly on subsoil $\mathrm{C}$ dynamics (Fig. 3). In any case, SOC pools on a mass basis were only marginally affected by the land use change as compared to $\mathrm{C}$ stored in tree biomass. Forty years after land use conversion, $\mathrm{C}$ stock of tree biomass exceeded the one of the soil. In the old forest, trees almost stored three times as much $\mathrm{C}$ as soils (Fig. 3), although the $\mathrm{C}$ pool of the trees in this study is much larger than the average pool of $\sim 100 \mathrm{t} \mathrm{C} \mathrm{ha}^{-1}$ in the Swiss Alps (Hagedorn et al. 2010b). Thus, afforestation turned pasture into a $\mathrm{C}$ sink mainly by $\mathrm{C}$ accumulation in vegetation, whilst the effects on SOC were comparatively small; the increase of the SOC stocks of $20 \mathrm{t} \mathrm{C} \mathrm{ha}^{-1}$ following afforestation corresponds to only 20 and $5 \%$ of the average biomass $\mathrm{C}$ pool in the Alps or in this study, respectively.

Effects on soil C quality

In contrast to the moderate effects on total soil $\mathrm{C}$ stocks, spruce plantation strongly influenced the composition and quality of SOM and its vertical distribution in soils. After tree establishment, $\delta^{13} \mathrm{C}$ values in the surface mineral soil shifted from $-27 \%$ in the pasture towards $-25.5 \%$ in the mature forest. Despite the rather small difference of $1.5 \%$ between the two vegetation types, the increase of the isotopic ratio was very consistent (Fig. 4). The impact of vegetation on $\delta^{13} \mathrm{C}$ values decreased with soil depth, which implies a stronger dominance of older soil $\mathrm{C}$ in the subsoils (e.g., Richter et al. 1999). The lower $\delta^{13} \mathrm{C}$ values of the upper mineral soils under pasture than under old forest might partly reflect the $\mathrm{C}$ input from grass roots that are more depleted in ${ }^{13} \mathrm{C}$, while the larger difference in $\delta^{13} \mathrm{C}$ values between spruce roots and SOM in the old forest soils might result from a stronger discrimination during decomposition, which is indicative for a slower root turnover (Chen et al. 2005). However, it is beyond the scope of this study to fully assess the processes leading to the different $\delta^{13} \mathrm{C}$ values under pasture and forest, but we interpret it as evidence for a replacement of pasture by tree-derived $\mathrm{C}$ in SOM with time after afforestation.

Afforestation directly affects SOM dynamics through changes of the input pathways and the quantity and quality of plant residues (De Deyn et al. 2008). In the pasture, C-inputs into soils were mainly restricted to grass roots as most of the foliage was removed by grazing cattle. In the afforestations, by contrast, a substantial amount of $\mathrm{C}$ originates from needle fall. However, the accumulation of a forest floor suggests that only a small fraction of this needle litter was incorporated into the mineral soil. In a field experiment with ${ }^{13} \mathrm{C}$ labelled pine needles, Bird and Torn (2006) reported that $<1 \%$ of the pine $C$ were allocated from the organic layer into the A horizon within 1.5 years and Tate et al. (2011) estimated that only $1-2.2 \%$ of fresh ${ }^{14} \mathrm{C}$ labelled pine needles were transferred into the mineral soil within 1 year in a young pine stand. In addition to the aboveground litter input, afforestation also affects the belowground $\mathrm{C}$ dynamics through the characteristics of fine roots (Guo et al. 2007) representing a very important SOC source 
Fig. 6 Cumulative fluxes of $\mathrm{CO}_{2}( \pm \mathrm{SE})$ respired from the pasture $(n=16)$ and forest $(n=28)$ mineral soils $(0-5 \mathrm{~cm})$ and the organic layer (Oe) $(n=4)$ during 140 days of incubation as expressed $\mathrm{g}^{-1} \mathrm{SOC}$

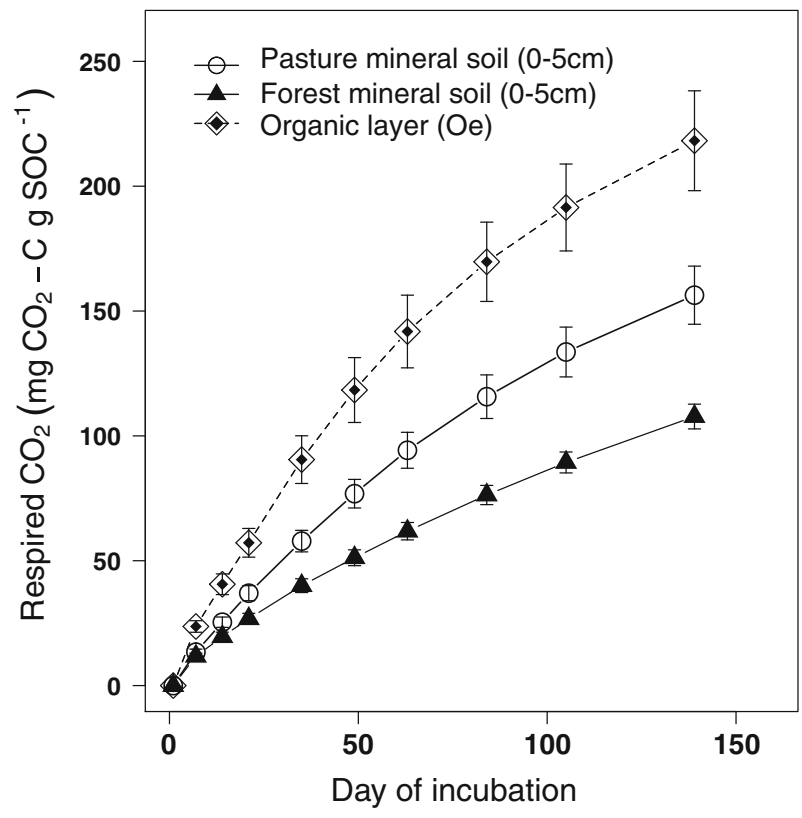

not soil C quality but other factors like microclimate or root respiration are primarily responsible for the higher soil respiration in the grassland than in the forest. Averaged over the growing season, surface soils under forest were about $5{ }^{\circ} \mathrm{C}$ cooler than under pasture. Given that soil temperature had a significant positive effect on the respiration $(P<0.001)$ and assuming a $Q_{10}$ of 3 (Hagedorn et al. 2010a), the lower soil temperature theoretically would lead to $50 \%$ lower soil respiration rates in the forests, which approximately was the case for the middle aged stands (30 and 40 years). In agreement with our data, Smith and Johnson (2004) measured $38 \%$ lower respiration rates after juniper encroachment on former grassland, which is also close to the $41 \%$ reduction reported by Kellman et al. (2007) in a comparison between pasture and two forests in Canada. In both studies, soil $\mathrm{CO}_{2}$ efflux was mainly attributed to a decline of soil temperature after tree establishment.

However, in addition to temperature, soil moisture can also be a critical factor for biological activity (Borken et al. 2003; Muhr and Borken 2009), especially when it drops below a minimum threshold (Curiel Yuste et al. 2003). According to our model, volumetric water content did not significantly affect respiration rates when fitted after temperature $(P=0.4)$. However, under dry conditions (volumetric $\mathrm{SWC}<20 \%$ ) respiration was rather limited. 
Fig. 7 Mean soil respiration in situ (a), cumulative fluxes of $\mathrm{CO}_{2}$ respired $\mathrm{g}^{-1}$ incubated soil after 140 days (b), and $\mathrm{CO}_{2}$ release $\mathrm{g}^{-1}$ soil after glucose addition (substrate induced respiration) (c) as affected by vegetation type and stand age. Note the different scales of the $y$-axis between mineral soils $(0-5 \mathrm{~cm})$ (left panel) and organic layers (right panel)

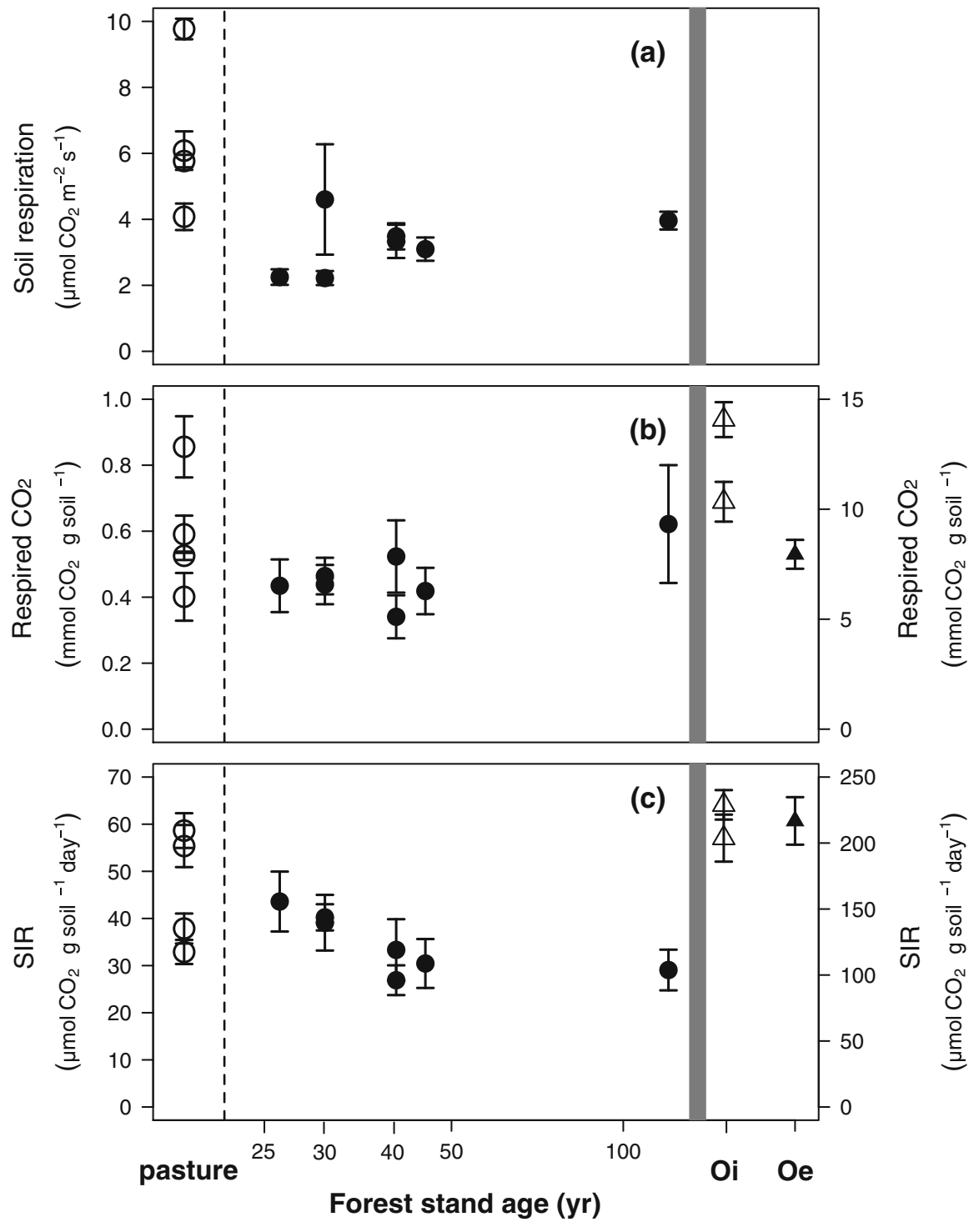

Moreover, $\mathrm{C}$ mineralization of the incubated organic layers was up to 20 times lower when the soil samples collected in fall 2011 were field moist and not adjusted to the optimal conditions during incubation (50\% of water holding capacity). This strongly suggests that water availability contributes to the control of SOM decomposition on this South facing slope, especially during the dry summer months. This is even more reasonable as a considerable amount of the respired $\mathrm{CO}_{2}$ in the forest originates from the organic layer (Buchmann 2000; Kammer et al. 2009), which is most susceptible to dry out. However, in our linear-mixed model, land use type still remained significant even after correcting for the soil temperature and moisture effects $(P=0.02)$. Therefore, additional factors must be at play, of which root respiration presumably is most important. Autotrophic respiration contributes about $50 \%$ to total soil respiration, but its proportion considerably varies throughout the year and among different vegetation types (Hanson et al. 2000). As the grassland soils had a $40 \%$ higher root biomass, it seems likely that autotrophic respiration was higher in the pasture than in the spruce stands. In summary, we interpret the $50 \%$ lower soil respiration in the forest than in the grassland as a combined effect of a 
colder and drier soil conditions, a reduced root respiration, and a lower SOM quality.

The fact that the lower $\mathrm{C}$ turnover under forest did not increase SOC storage - at least not in the short termsuggests that it must have been offset by a decreased C input from plants. This is in line with the findings of Scott et al. (2006), who attributed the concomitant decreases in $\mathrm{C}$ stocks and soil respiration rates after pine afforestation to a declined $\mathrm{C}$ input into the mineral soil. On a larger scale compiling Eddy flux data across Europe, Schulze et al. (2010) reported that both heterotrophic respiration rates and net primary production in forests are considerably lower than in grasslands, which supports our conclusion of a reduced $\mathrm{C}$ input after afforestation. The highest SOC stocks in the more than 120-year old forest, however, show that afforestation has a positive effect on soil C storage in this subalpine ecosystem.

\section{Conclusions}

Our results show that spruce afforestation on an extensively grazed alpine pasture had only small effects on total soil $\mathrm{C}$ storage. Soil $\mathrm{C}$ stocks in the mineral soil transiently decreased after tree establishment, reaching a minimum 40-45 years after afforestation and increased again thereafter. Soils of the mature spruce forest ( $>120$ years) stored more $\mathrm{C}$ than pasture soils, mainly due to the accumulation of an organic layer. In contrast to soil C stocks, afforestation strongly altered SOM quality with forest soils containing lower fractions of labile SOM and having higher $\mathrm{C}: \mathrm{N}$ ratios as pasture soils. Soil respiration significantly decreased after the land use change probably primarily due to a less favorable microclimate for decomposition of SOM and reduced root respiration in the forests. This implies, in conjunction with the moderate effects on total soil $\mathrm{C}$ stocks that $\mathrm{C}$ inputs into soils and hence also ecosystem $\mathrm{C}$ cycling rates must have decreased considerably with afforestation. However, the high soil C stocks in the old forest strongly suggest that on a centennial time scale, afforestation has positive effects on soil $\mathrm{C}$ storage, but this increase is small as compared to $\mathrm{C}$ accumulated in tree biomass.

Acknowledgments We gratefully thank P. A. Niklaus for the measurement of the gas samples, M. Walser and R. Köchli for the field assistance and G.D. Lieberherr, A. Zürcher and C. Herzog for assistance in the laboratory. This study was funded by the COST Action 639 (BurnOut) and the Swiss Federal Office for the Environment (FOEN).

\section{References}

Berg G, Smalla K (2009) Plant species and soil type cooperatively shape the structure and function of microbial communities in the rhizosphere. FEMS Microbiol Ecol 68(1): $1-13$

Bird JA, Torn MS (2006) Fine roots vs. needles: a comparison of ${ }^{13} \mathrm{C}$ and ${ }^{15} \mathrm{~N}$ dynamics in a ponderosa pine forest soil. Biogeochemistry 79(3):361-382

Bolliger J, Hagedorn F, Leifeld J, Boehl J, Zimmermann S, Soliva R, Kienast F (2008) Effects of land-use change on carbon stocks in Switzerland. Ecosystems 11(6):895-907

Borken W, Davidson EA, Savage K, Gaudinski J, Trumbore SE (2003) Drying and wetting effects on carbon dioxide release from organic horizons. Soil Sci Soc Am J 67(6): 1888-1896

Brändli U-B (2010) Schweizerisches Landesforstinventar. Ergebnisse der dritten Erhebung 2004-2006. Birmensdorf, Eidgenössische Forschungsanstalt für Wald, Schnee und Landschaft WSL. Bern, Bundesamt für Umwelt, BAFU

Buchmann N (2000) Biotic and abiotic factors controlling soil respiration rates in Picea abies stands. Soil Biol Biochem 32(11-12):1625-1635

Budge K, Leifeld J, Hiltbrunner E, Fuhrer J (2011) Alpine grassland soils contain large proportion of labile carbon but indicate long turnover times. Biogeosciences 8(7):19111923

Chen QQ, Shen CD, Sun YM, Peng SL, Yi WX, Li ZA, Jiang MT (2005) Spatial and temporal distribution of carbon isotopes in soil organic matter at the Dinghushan Biosphere Reserve, South China. Plant Soil 273(1-2):115-128

Cheng WX, Virginia RA (1993) Measurement of microbial biomass in arctic tundra soils using fumigation extraction and substrate-induced respiration procedures. Soil Biol Biochem 25(1):135-141

Curiel Yuste J, Janssens IA, Carrara A, Meiresonne L, Ceulemans R (2003) Interactive effects of temperature and precipitation on soil respiration in a temperate maritime pine forest. Tree Physiol 23(18):1263-1270

De Deyn GB, Cornelissen JHC, Bardgett RD (2008) Plant functional traits and soil carbon sequestration in contrasting biomes. Ecol Lett 11(5):516-531

Dence CW (1992) The determination of lignin. In: Lin SY, Dence CW (eds) Methods in lignin chemistry. SpringerVerlag, Berlin, pp 33-61

Fontaine S, Barot S, Barre P, Bdioui N, Mary B, Rumpel C (2007) Stability of organic carbon in deep soil layers controlled by fresh carbon supply. Nature 450:277-281

Gee GW, Bauder JW (1986) Particle size analysis. In: Klute A (ed) Methods of soil analysis. Part 1. Physical and mineralogical methods. American Society of Agronomy, Madison, pp 386-411

Guo LB, Gifford RM (2002) Soil carbon stocks and land use change: a meta analysis. Glob Change Biol 8(4):345-360

Guo LB, Wang M, Gifford RM (2007) The change of soil carbon stocks and fine root dynamics after land use change from a 
native pasture to a pine plantation. Plant Soil 299(1-2): 251-262

Hagedorn F, Martin M, Rixen C, Rusch S, Bebi P, Zuercher A, Siegwolf RTW, Wipf S, Escape C, Roy J, Haettenschwiler $S$ (2010a) Short-term responses of ecosystem carbon fluxes to experimental soil warming at the Swiss alpine treeline. Biogeochemistry 97(1):7-19

Hagedorn F, Moeri A, Walthert L, Zimmermann S (2010b) Kohlenstoff in Schweizer Waldböden-bei Klimaerwärmung eine potenzielle $\mathrm{CO}_{2}$-Quelle. Schweizerische Zeitung für Forstwesen 161(12):530-535

Hagedorn F, Mulder J, Jandl R (2010c) Mountain soils under a changing climate and land-use. Biogeochemistry 97(1): $1-5$

Hanson PJ, Edwards NT, Garten CT, Andrews JA (2000) Separating root and soil microbial contributions to soil respiration: a review of methods and observations. Biogeochemistry 48(1):115-146

Harrison RB, Footen PW, Strahm BD (2011) Deep soil horizons: contribution and importance to soil carbon pools and in assessing whole-ecosystem response to management and global change. For Sci 57(1):67-76

Hiltbrunner D, Zimmermann S, Karbin S, Hagedorn F, Niklaus PA (2012) Increasing soil methane sink along a 120-year afforestation chronosequence is driven by soil moisture. Glob Change Biol. doi:10.1111/j.1365-2486.2012.02798.x

Hitz C, Egli M, Fitze P (2001) Below-ground and above-ground production of vegetational organic matter along a climosequence in alpine grasslands. J Plant Nutr Soil Sci 164(4): 389-397

Hooker TD, Compton JE (2003) Forest ecosystem carbon and nitrogen accumulation during the first century after agricultural abandonment. Ecol Appl 13(2):299-313

Houghton RA (2003) Revised estimates of the annual net flux of carbon to the atmosphere from changes in land use and land management 1850-2000. Tellus B 55(2):378-390

Jackson RB, Canadell J, Ehleringer JR, Mooney HA, Sala OE, Schulze ED (1996) A global analysis of root distributions for terrestrial biomes. Oecologia 108(3):389-411

Jandl R, Lindner M, Vesterdal L, Bauwens B, Baritz R, Hagedorn F, Johnson DW, Minkkinen K, Byrne KA (2007) How strongly can forest management influence soil carbon sequestration? Geoderma 137(3-4):253-268

Kammer A, Hagedorn F, Shevchenko I, Leifeld J, Guggenberger G, Goryacheva T, Rigling A, Moiseev P (2009) Treeline shifts in the Ural mountains affect soil organic matter dynamics. Glob Change Biol 15(6):1570-1583

Kaufmann E (2001) Estimation of standing timber, growth and cut. In: Brassel P, Lischke H (eds) Swiss National Forest Inventory: methods and models of the second assessment. Swiss Federal Research Institute WSL, Birmensdorf, pp 162-196

Kellman L, Beltrami H, Risk D (2007) Changes in seasonal soil respiration with pasture conversion to forest in Atlantic Canada. Biogeochemistry 82(1):101-109

Leifeld J, Bassin S, Fuhrer J (2005) Carbon stocks in Swiss agricultural soils predicted by land-use, soil characteristics, and altitude. Agric Ecosyst Environ 105(1-2):255-266

Leifeld J, Zimmermann M, Fuhrer J, Conen F (2009) Storage and turnover of carbon in grassland soils along an elevation gradient in the Swiss Alps. Glob Change Biol 15(3): 668-679
MacDonald D, Crabtree JR, Wiesinger G, Dax T, Stamou N, Fleury P, Lazpita JG, Gibon A (2000) Agricultural abandonment in mountain areas of Europe: environmental consequences and policy response. J Environ Manage 59(1):47-69

Macdonald CA, Thomas N, Robinson L, Tate KR, Ross DJ, Dando J, Singh BK (2009) Physiological, biochemical and molecular responses of the soil microbial community after afforestation of pastures with Pinus radiata. Soil Biol Biochem 41(8):1642-1651

Mobley ML (2011) An ecosystem approach to dead plant carbon over 50 years of old-field forest. Dissertation, Duke University

Muhr J, Borken W (2009) Delayed recovery of soil respiration after wetting of dry soil further reduces $\mathrm{C}$ losses from a Norway spruce forest soil. J Geophys Res 114:G04023

Ouimet R, Tremblay S, Perie C, Pregent G (2007) Ecosystem carbon accumulation following fallow farmland afforestation with red pine in southern Quebec. Can J For Res 37(6):1118-1133

Paul KI, Polglase PJ, Nyakuengama JG, Khanna PK (2002) Change in soil carbon following afforestation. For Ecol Manage 168(1-3):241-257

Poeplau C, Don A, Vesterdal L, Leifeld J, Van Wesemael B, Schumacher J, Gensior A (2011) Temporal dynamics of soil organic carbon after land-use change in the temperate zone-carbon response functions as a model approach. Glob Change Biol 17(7):2415-2427

Post WM, Kwon KC (2000) Soil carbon sequestration and landuse change: processes and potential. Glob Change Biol 6(3):317-327

R: Development Core Team (2010) R: a language and environment for statistical computing. R Foundation for Statistical Computing, Vienna

Rasse DP, Rumpel C, Dignac MF (2005) Is soil carbon mostly root carbon? Mechanisms for a specific stabilisation. Plant Soil 269(1-2):341-356

Richter DD, Markewitz D, Trumbore SE, Wells CG (1999) Rapid accumulation and turnover of soil carbon in a reestablishing forest. Nature 400(6739):56-58

Risch AC, Jurgensen MF, Page-Dumroese DS, Wildi O, Schütz M (2008) Long-term development of above- and belowground carbon stocks following land-use changes in subalpine ecosystems of the Siwss National Park. Can J For Res 38:1590-1602

Schulze ED, Ciais P, Luyssaert S, Schrumpf M, Janssens IA, Thiruchittampalam B, Theloke J, Saurat M, Bringezu S, Lelieveld J, Lohila A, Rebmann C, Jung M, Bastviken D, Abril G, Grassi G, Leip A, Freibauer A, Kutsch W, Don A, Nieschulze J, Boerner A, Gash JH, Dolman AJ (2010) The European carbon balance. Part 4: integration of carbon and other trace-gas fluxes. Glob Change Biol 16(5):1451-1469

Scott NA, Tate KR, Ross DJ, Parshotam A (2006) Processes influencing soil carbon storage following afforestation of pasture with Pinus radiata at different stocking densities in New Zealand. Aust J Soil Res 44(2):85-96

Sjögersten-Turner S, Alewell C, Cécillion L, Hagedorn F, Jandl R, Leifield J, Martinsen V, Sebastia T, Van Miegroet H (2011) Mountain soils in a changing climate-vulnerability and ecosystem feedbacks. In: Jandl R, Rodeghiero M, Olsson M (eds) Soil carbon in sensitive European 
ecosystems: from science to land management. Wiley, Chichester, pp 118-148

Smith DL, Johnson L (2004) Vegetation-mediated changes in microclimate reduce soil respiration as woodlands expand into grasslands. Ecology 85(12):3348-3361

Tappeiner U, Tappeiner G, Hilbert A, Mattanovich E (2003) The EU agricultural policy and the environment. Evaluation of the Alpine region. Blackwell, Berlin

Tasser E, Walde J, Tappeiner U, Teutsch A, Noggler W (2007) Land-use changes and natural reforestation in the Eastern Central Alps. Agric Ecosyst Environ 118(1-4):115-129

Tate KR, Lambie SM, Ross DJ, Dando J (2011) Carbon transfer from ${ }^{14} \mathrm{C}$-labelled needles to mineral soil, and ${ }^{14} \mathrm{C}-\mathrm{CO}_{2}$ production, in a young Pinus radiata Don stand. Eur J Soil Sci 62(1):127-133

Thuille A, Schulze ED (2006) Carbon dynamics in successional and afforested spruce stands in Thuringia and the Alps. Glob Change Biol 12(2):325-342
Walthert L, Graf U, Kammer A, Luster J, Pezzotta D, Zimmermann S, Hagedorn F (2010) Determination of organic and inorganic carbon, delta C-13, and nitrogen in soils containing carbonates after acid fumigation with HCI. J Plant Nutr Soil Sci 173(2):207-216

Wei X, Qiu L, Shao M, Zhang X, Gale WJ (2012) The accumulation of organic carbon in mineral soils by afforestation of abandoned farmland. PLoS One 7(3):e32054

Wiesmeier M, Spoerlein P, Geuss U, Hangen E, Haug S, Reischl A, Schilling B, von Luetzow M, Koegel-Knabner I (2012) Soil organic carbon stocks in southeast Germany (Bavaria) as affected by land use, soil type and sampling depth. Glob Change Biol 18(7):2233-2245 